\title{
Effect of the Carburizing Layer on the Morphology of Chromium Carbides
}

\author{
Rabah Boubaaya*a,b, Omar Allaoui ${ }^{\text {, }}$ \\ Younes Benarioua ${ }^{\mathbf{c}}$ and Zied Driss ${ }^{d}$ \\ aDépartement S.T, Faculté des Sciences et de la Technologie, \\ Université Mohamed El Bachir El Ibrahimi de Bordj Bou Arreridj \\ Algeria \\ ${ }^{b}$ Laboratoire de Génie des procédés, \\ Université Amar Telidji-Laghouat \\ Algeria \\ 'Département de Génie Mécanique, Faculté de Technologies, \\ Université de M'sila \\ Algeria \\ ${ }^{d}$ Laboratory of Electro-Mechanic Systems (LASEM) \\ National School of Engineers of Sfax (ENIS), University of Sfax (US)
}

Abstract. Low carbon steel substrates were face-hardened by cementing, after which thin layers of chromium were deposited electrolytically on these substrates. After deposition, the samples were exposed to isothermal annealing at a temperature of $950^{\circ} \mathrm{C}$. The characterization of the thin layers was carried out by means of optical microscopy and interferometry using the Vickers microhardness test. The obtained results allowed establishing the phase shift kinetics (under the effect of the cementing layer) in thin layers of chromium, which are transformed into chromium carbide when passing through metastable transition phases. These transformations were due to diffusion of the carbon atoms coming from the layer of cementing, germination and growth in solid phase. This fact has been examined taking into account the annealing temperature, the lattice parameter evolution and the deposited chromium layer morphology. As to mechanical properties, it was established that the micro-hardness depends on the phase shift evolution.

Keywords: steel, chromium, cementing, chromium carbide, diffusion, precipitation, deposition.

Citation: Boubaaya R., Allaoui O., Benarioua Yo., Driss Z. Effect of the carburizing layer on the morphology of chromium carbides, J. Sib. Fed. Univ. Eng. \& Technol., 2020, 13(2), 187-193. DOI: 10.17516/1999-494X-0215

C Siberian Federal University. All rights reserved

This work is licensed under a Creative Commons Attribution-NonCommercial 4.0 International License (CC BY-NC 4.0).

* Corresponding author E-mail address: raboubaaya@yahoo.fr 


\title{
Влияние углеродного слоя
}

\section{на морфологию карбидов хрома}

\author{
Рабах Бубайа ${ }^{\text {a, }}$, Омар Аллауи ${ }^{\tilde{0}}$ \\ Юнес Бенариуа ${ }^{\mathrm{B}}$, Зиед Дрисс \\ ${ }^{a}$ Научно-технический факультет, \\ Университет Мохаммеда эль-Бачира-эль-Ибрахими \\ в Бордж-Бу-Арреридже, Алжир \\ ${ }^{6}$ Технологическая лаборатория, \\ Университет Амара Телиджи де Лагуат \\ Алжир \\ ${ }^{6}$ Кафедра машиностроения, технологический факультет, \\ Университет Мсила \\ Алжир \\ ¿Лаборатория электромеханических систем, \\ инженерный факультет, Университет Сфакса
}

Аннотация. Стальные подложки с низким содержанием углерода подвергали поверхностному упрочнению путем цементирования, а затем на эти подложки электролитическим способом осаждали тонкие слои хрома. После осаждения образцы подвергали изотермическому отжигу при температуре $950^{\circ} \mathrm{C}$. Характеристика тонких слоев производилась с помощью оптической микроскопии и интерферометрии по микротвердости по Виккерсу. На основании полученных результатов установлена кинетика фазового сдвига (под действием слоя цементирования) в тонких слоях хрома, которые превращаются в карбид хрома при прохождении метастабильных фаз перехода. Эти превращения происходили путем диффузии атомов углерода, поступающих из слоя цементирования, прорастания и роста в твердой фазе. Данный факт исследовали в зависимости от температуры отжига, эволюции параметра решетки и морфологии осажденного слоя хрома. Что касается механических свойств, было установлено, что микротвердость зависит от эволюции фазового сдвига.

Ключевые слова: сталь, хром, цементирование, карбид хрома, диффузия, осаждение, нанесение.

Цитирование: Бубайа, Рабах. Влияние углеродного слоя на морфологию карбидов хрома / Рабах Бубайа, Омар Аллауи, Юнес Бенариуа, Зиед Дрисс // Журн. Сиб. федер. ун-та. Техника и технологии, 2020. 13(2). С. 187-193. DOI: 10.17516/1999-494X-0215

\section{Introduction}

Over the past two decades, the transition metal carbides for the coatings have been found to be one of the most effective materials for increasing the life time of machine components, cutting and forming tools, as they can significantly improve wear and corrosion resistance $[1,2]$. Among these metal compounds, chromium carbide has the best mechanical and chemical resistance in harsh conditions. Recent research on chromium carbide stressed its resistance to oxidation and corrosion and suggested that it has a great potential to replace hard chrome electroplating as protective coatings $[3,4]$. The chromium carbide layers can be obtained by physical vapor deposition (PVD) $[5,6]$ or 
thermo-reactive deposition/diffusion (TRD) technology [7, 8]. PVD provides thickness much less than $10 \mu \mathrm{m}$ which is not enough to withstand the high contact pressure. Further adhesion to the substrate is less than that obtained by other types of coating techniques. TRD coatings have very long process time at high temperatures. For example, an $8 \mu \mathrm{m}$ thickness chromium carbide layer was obtained on steel AISI D2 with a treatment at $1030^{\circ} \mathrm{C}$ for $4 \mathrm{~h}$ [9] and $13 \mu \mathrm{m}$ thickness was obtained with treatment at $1000^{\circ} \mathrm{C}$ for $3 \mathrm{~h}$ [10]. Indeed, there are very common industrial methods that can be combined in any manner to produce chromium carbide coatings.

In order to produce a high-hardness coating with good adhesive properties and sufficient thickness able to withstand severe loading conditions, we propose an alternative technique based on a threestep process using only standard industrial methods. The first step intends to increase the carbon content at the surface of the substrate using a standard carburizing process. The second step consists in coating the carburized material with a layer of chromium. The final step includes the heat treatment at temperatures which allow the diffusion of carbon into the surface of the material. In this work, we propose to determine the experimental conditions which allow complete conversion of the chromium layer in a uniform layer of high hardness of chromium carbide and a good adhesion to the substrate.

\section{Experimental methods}

\subsection{Materials and coating deposition}

Cylindrical samples with a diameter of $20 \mathrm{~mm}$ and a length of $15 \mathrm{~mm}$ were selected. The chemical composition of the substrate was determined by spectrometric analysis using a spectrometer HILGER.

The preparation of the substrate consists in mechanically polishing each sample using abrasive paper. The finishing operation provides good polishing with felt washed down with a suspension of alumina in water. The polished surface must be thoroughly cleaned with water, dried with compressed air and subjected to hot filtration. To conduct a comparative study, we divided the samples into 4 groups.

Table 1. Chemical composition of the steel to be coated (\%)

\begin{tabular}{|c|c|c|c|c|c|c|}
\hline $\mathbf{F e}$ & $\mathbf{C}$ & $\mathbf{S i}$ & $\mathbf{M n}$ & $\mathbf{P}$ & $\mathbf{S}$ & $\mathbf{C r}$ \\
\hline 95.99 & 0.19 & 0.22 & 0.94 & 0.003 & 0.056 & 1.12 \\
\hline $\mathbf{M o}$ & $\mathbf{N i}$ & $\mathbf{A l}$ & $\mathbf{C o}$ & $\mathbf{C u}$ & $\mathbf{T i}$ & $\mathbf{S n}$ \\
\hline 0.07 & 1.18 & 0.0116 & 0.01 & 0.20 & 0.0012 & 0.010 \\
\hline
\end{tabular}

Table 2. Carburizing test parameters

\begin{tabular}{|l|c|c|c|c|}
\hline \multicolumn{1}{|c|}{ Group } & I & II & III & IV \\
\hline Hold time & 00 & 03 hours & 06 hours & 12 hours \\
\hline Cementing thickness & E1 $=00 \mathrm{~mm}$ & E2 $=0.6 \mathrm{~mm}$ & E3 $=1.3 \mathrm{~mm}$ & E4 $=2.5 \mathrm{~mm}$ \\
\hline Temperature & & $900^{\circ} \mathrm{C}$ & $900^{\circ} \mathrm{C}$ & $900^{\circ} \mathrm{C}$ \\
\hline
\end{tabular}


Cementing is performed using cement coke powder. To accelerate cementing, barium carbonates $\mathrm{BaCO}_{3}$ are added to coal activators.

Samples were subjected to chrome electroplating, the standard composition of plating bath: $250 \mathrm{~g} / 1 \mathrm{CrO} 3,2.5 \mathrm{~g} / 1 \mathrm{SO} 4 \mathrm{H} 2$, bath temperature $\left(40-44^{\circ} \mathrm{C}\right)$, antimony and lead anode, retention time $1 / 2$ hour and deposition rate of about $40 \mu \mathrm{m} / \mathrm{h}$. In order to obtain a layer of chromium carbide, chromium coated samples were exposed to thermal annealing treatment at a temperature of $950^{\circ} \mathrm{C}$. The retention time is 01 hour.

\subsection{Characterization and analysis techniques}

Microscopic observation requires fine polishing of the surface or a cut of deposits to be observed. Cleaning with acetone and drying with a hot air flow stop mechanical polishing. The second stage consists of chemical exposure using the nital product, the composition and volume proportions of which include nitric acid $(5 \mathrm{ml})$ and ethanol $(95 \mathrm{ml})$. Chemical etching can reveal different phases present in an optical microscope. The equipment used is a universal optical metallographic microscope of the ZEISS type.

The Vickers micro-hardness test allows measuring the size of indentation deposited on a precipitate. Measurements of micro-hardness of the deposits have been made on surfaces of polished sections. Indentations under a load of 50 grams were made using a Buehler MICROMET type micro durometer (HARDNESS TESTER), which is equipped with a Vickers diamond indenter.

The samples have been tested in Vickers micro-hardness with five measurements on each sample. Given the average value obtained for five fingerprints, it is possible to reduce measurement errors.

\section{Results and discussion}

\subsection{Morphology}

Fig. 1 shows the observation of metallographic faces layer/substrate after annealing at $950^{\circ} \mathrm{C}$. From these results, it has been observed that no traces of chromium carbide could be found in the pictures corresponding to the sample without cementation $(\mathrm{E} 1=0 \mathrm{~mm})$. The sample of group II $(\mathrm{E} 2=0.6 \mathrm{~mm})$, a chromium carbide edge occurs in the vicinity of the interface. This fact is reflected by the low diffusion of carbon cementation zone in the deposited chromium layer. In the picture corresponding to the sample of group III $(\mathrm{E} 3=1.3 \mathrm{~mm})$, it has been noted that the microstructure is predominantly in chips arranged on the substrate surface. This kind of morphology is found in several cases of phase change in the solid state. The structure of the incipient phase is usually in the form of needles certain plane oriented parallel to the surrounding parent phase. Increasing the amount of carbon diffusion from the substrate causes a progressive propagation of chromium carbide in the deposition of chromium. For the sample of group IV (E4 $=2.5 \mathrm{~mm}$ ), chromium matrix is transformed completely to chromium carbides. The formed layer has a granular structure. The morphology of the deposit of chromium carbides mainly depends on the treatment temperature, which promotes the mobility of atoms in the layer and the substrate. Mobility supports the movement of the diffusion carbon element from the substrate to the layer.

Indeed, the thickness of the carburized layer has a great effect on the rate of conversion of chromium into chromium carbides. 


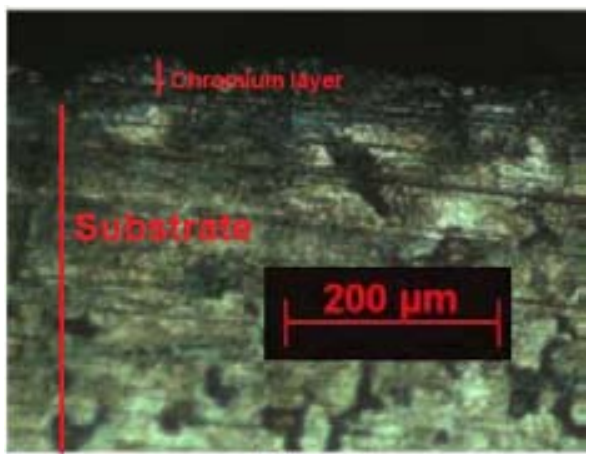

(a)

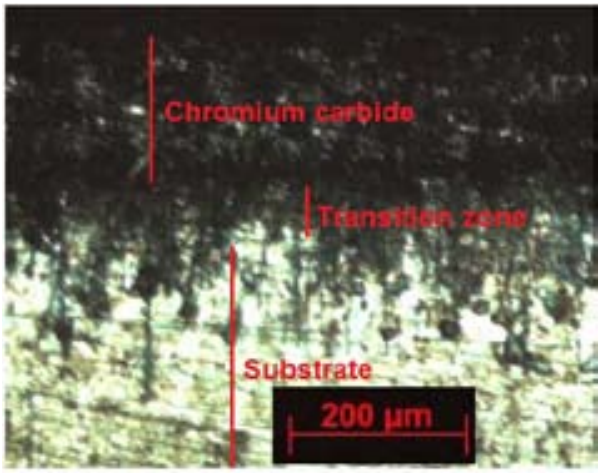

(c)

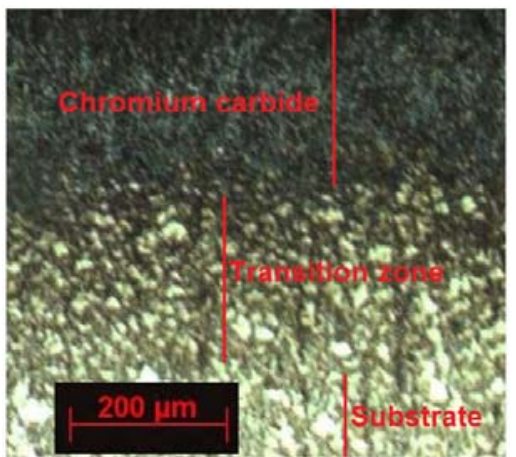

(b)

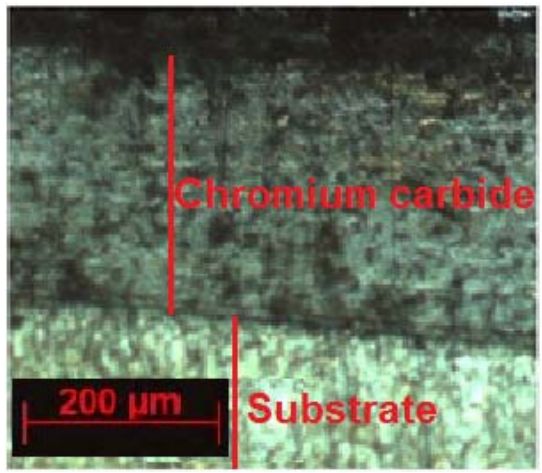

(d)

Fig. 1. Observation of metallographic faces layer/substrate after annealing at $950^{\circ} \mathrm{C}$ : (a) the sample of group I $\left(E_{1}=0 \mathrm{~mm}\right)$, (b) the sample of group II $\left(E_{2}=0.6 \mathrm{~mm}\right)$, (c) the sample of group III $\left(E_{3}=1.3 \mathrm{~mm}\right)$, (d) the sample of group IV $\left(\mathrm{E}_{4}=2.5 \mathrm{~mm}\right)$

\subsection{Micro-hardness}

Fig. 2 shows the effect of the thicknesses of the carburizing layer on the micro-hardness. According to these results, it is clear that the micro-hardness is still evolving in ascending order. Micro-hardness measurements made on samples $\mathrm{E}_{3}$ and $\mathrm{E}_{4}$ show that the micro-hardness is even greater than that of the samples $E_{1}$ and $E_{2}$ (Table 3). Curing will be associated with the complete formation of chromium carbide, which will lead to increased deposits. Diffusion of carbon atoms reaches the outer surface of the layer; the atoms occupy the chromium surface interstices; thus, it will be a total loss of chromium phase.

Under these conditions, the thicknesses of the carburizing layer $\mathrm{E}_{2}, \mathrm{E}_{3}$ and $\mathrm{E}_{4}$ are $0.6 \mathrm{~mm}, 1.3 \mathrm{~mm}$ and $2.5 \mathrm{~mm}$ respectively. Based on these results, we can confirm that the difference between the cementation thicknesses may cause a difference in micro-hardness. 
Table 3. Change in micro-hardness depending on the thicknesses of the carburizing layer

\begin{tabular}{|c|c|}
\hline Thicknesses of the carburizing layer & Micro-hardness (HV) \\
\hline $\begin{array}{c}\text { E1 }=0 \mathrm{~mm} \\
\text { Without cementation }\end{array}$ & 390 \\
\hline $\mathrm{E} 2=0.6 \mathrm{~mm}$ & 1880 \\
\hline $\mathrm{E} 3=1.3 \mathrm{~mm}$ & 2110 \\
\hline $\mathrm{E} 4=2.5 \mathrm{~mm}$ & 2615 \\
\hline
\end{tabular}

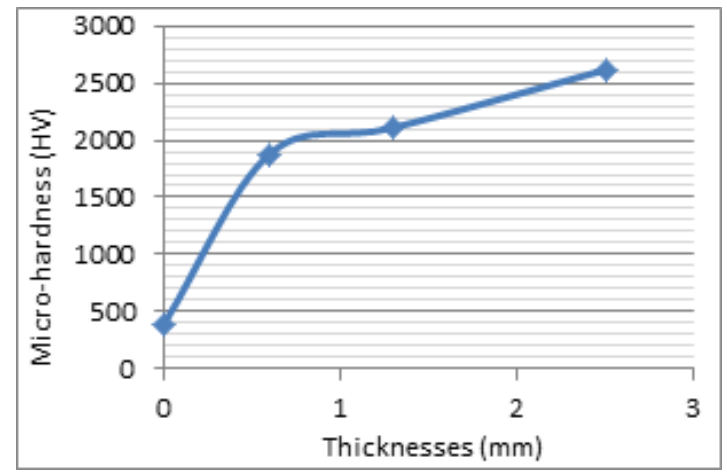

Fig. 2. Effect of thicknesses of the carburizing layer on the micro-hardness

\section{Conclusion}

In this paper, we are interested in the increased performance of chromium carbide steel creation with high features. For this purpose, a chromium layer on the steel samples (layer / substrate) was subjected to annealing at $950^{\circ} \mathrm{C}$ after carburizing and deposition by electroplating. At this temperature, the deposited film is gradually converted to chromium carbide. Phase transformation, which took place primarily by diffusion of the substrate carbon atoms in the layer, was determined by metallographic analysis. The hardness of the obtained layers varied depending on the thickness of the carburized layer. The obtained value is in agreement with the changing properties determined by the $\mathrm{x}$-ray diffraction and microscopic observation.

Indeed, it has been noted that for a sample without cementation $(\mathrm{E} 1=0 \mathrm{~mm})$, thin films retain their monophasic character, the micro-hardness of the deposited initial layer is greater than that of the treated one. It should be noted that for the sample of group II (E2 $=0.6 \mathrm{~mm})$ and the sample of group III $(\mathrm{E} 3=1.3 \mathrm{~mm})$, the incipient phase is increased while the chromium mother phase undergoes a decrease. This causes a high hardening of the obtained deposit. For the sample of group IV (E4 $=2.5 \mathrm{~mm}$ ), the chromium layer is completely converted into chromium carbides that would be responsible for the increase of the hardness.

In this case, it is both the thicknesses of the carburization layers and temperature treatment which play an essential role in the transformation of the chromium layer to chromium carbides.

\section{References}

[1] Yan-mei Jiang I. Cathodic spray aided by computer, thesis of Orsay University, 1992. 
[2] Vossen J.L. and Kern W. Thin film processes, Ed.Academic press, 1978.

[3] Bosseboeuf A. Thesis, Orsay, 1989, p. 223.

[4] Bouchier D. Thesis, Orsay, 1985, p. 122.

[5] Dijkkamp D., Min-Lee Y.H. and Mc W.L. Appl.Phys.Lett. 1987, 51, 619.

[6] Prôner A. Thermal spray coatings, Engineering Techniques, (MD3), M1645, 11-12.

[7] Pfender E. Fundamental Studies Associated with the Plasma Spray Process, Thermal Spray, Advances in Coatings Technology, (Ed.) C.C Berndt, (Pb.) ASM International, Materials Park, Ohio, USA, 1992, 1-10.

[8] Matsushima T. Thesis of Osaka University, Japan, 1991.

[9] Wei C.Y. Chen, F.S. Mater. Chem. Phys. 2005, 91, 192.

[10] Sen S. Mater. Des. 2006, $27,85$. 